\title{
EVALUASI RUANG PUBLIK SEBAGAI RUANG SOSIAL YANG RAMAH ANAK PADA PEREMAJAAN RUSUNAWA TAMBORA
}

\author{
Mekar Sari Suteja ${ }^{1}$ Dewi Ratnaningrum $^{2}$, Diah Anggraini ${ }^{3}$ \\ ${ }^{1}$ Program Studi Sarjana Arsitektur, Universitas Tarunamanaga, Jakarta \\ Surel: mekars@untar.ac.id \\ ${ }^{2}$ Program Studi Sarjana Arsitektur, Universitas Tarunamanaga, Jakarta \\ Surel: dewiratnaningrum13@yahoo.com \\ ${ }^{3}$ Program Studi Sarjana Arsitektur, Universitas Tarunamanaga, Jakarta \\ Surel: diah_ismono@yahoo.com
}

\begin{abstract}
The policy on the implementation of development and maintenance of Child Friendly Integrated Public Spaces (RPTRA) in early 2015 is an effort of the Jakarta Provincial Government to increase social interaction between residents living in high-density dwellings so that mutual cooperation can be formed. The acceleration of the construction of Flats and its renovation, which is largely devoted to Low-Income Communities in Jakarta and demanding efficient land use, is often not child-friendly and ignores the need for social interaction of citizens on the grounds of being able to get large public open spaces. This research was conducted at the Tambora Baru Flats which was the result of renovation of the old towers that were already unfit for both physical, and social problems of the residents (Ratnaningrum \& Suteja, 2012). This study aims to evaluate the post-habitation use of child-friendly public spaces that occur in shared spaces in the Tambora Baru Flats, which is considered as one of the 3 pilot Flats in Jakarta. The method used is qualitative descriptive which refers to the post-occupancy evaluation method. Data collection was carried out using participant observation method, in-depth interviews and Focus Group Discussions (FGD), as well as through surveys with questionnaires, photographs and mapping. The result of this study is expected to be an input for the design and provision of public space as child-friendly social interaction space in the construction or renovation of high-rise flats in Jakarta.
\end{abstract}

Keywords: evaluation, public space, social space and child friendly

\begin{abstract}
ABSTRAK
Kebijakan mengenai pelaksanaan pembangunan dan pemeliharaan Ruang Publik Terpadu Ramah Anak (RPTRA) pada awal tahun 2015 merupakan usaha Pemprov DKI dalam meningkatkan interaksi sosial antar warga yang tinggal di hunian berkepadatan tinggi agar sifat kegotong-royongan mereka dapat terjalin. Percepatan pembangunan Rumah Susun dan peremajaannya yang sebagian besar dikhususkan bagi Masyarakat Berpenghasilan Rendah di DKI Jakarta dan menuntut efisiensi penggunaan lahan, seringkali tidak ramah anak dan mengabaikan kebutuhan interaksi sosial warga dengan alasan untuk dapat mendapatkan ruang terbuka publik yang besar. Penelitian ini dilakukan pada Rusunawa Tambora Baru yang merupakan hasil peremajaan dari rusun lama yang sudah tidak layak huni baik secara fisik dan masalah sosial penghuni (Ratnaningrum \& Suteja, 2012). Penelitian ini bertujuan untuk mengevaluasi pasca huni pemanfaatan ruang publik ramah anak yang terjadi di ruang-ruang bersama pada Rusunawa Tambora Baru, yang dianggap sebagai salah satu dari 3 Rusunawa percontohan di DKI Jakarta. Metode yang dilakukan bersifat diskripsi kualitatif dan mengacu pada metode evaluasi pasca huni. Pengumpulan data dilakukan dengan metode observasi partisipatif, wawancara mendalam dan Focus Group Discussion (FGD), serta melalui survey dengan kuisioner, pembuatan foto dan pemetaan. Hasil penelitian ini diharapkan dapat menjadi masukan bagi perancangan dan penyediaan ruang publik sebagai ruang interaksi sosial yang ramah anak pada pembangunan atau peremajaan rusunawa-rusunawa berlantai tinggi di Jakarta.
\end{abstract}

Kata kunci: evaluasi, ruang publik, ruang sosial dan ramah anak 


\section{PENDAHULUAN}

\section{Latar Belakang}

Daya tampung kota yang terbatas dan pertumbuhan penduduk yang terus berlangsung, sementara itu besarnya pemenuhan kebutuhan tempat tinggal terutama bagi masyarakat berpenghasilan rendah di kota-kota besar menjadi salah satu masalah yang harus dipecahkan (Purwaningsih, Tukiran, \& Giyarsih, 2011). Pembangunan Rumah Susun Sederhana Sewa (Rusunawa) merupakan salah satu program Pemerintah Provinsi DKI Jakarta untuk mengatasi permasalahan ini (Suminah, Sulistyantara, \& Budiarti, 2017). Preferensi masyarakat dalam pemilihan hunian yang nyaman dipengaruhi oleh faktor fisik lingkungan hunian, sosial, ekonomi dan budaya masyarakat (Boumeester dalam Irfiyanti \& Widjonarko). Untuk menuju pembangunan berdasarkan pada amanat Undang-Undang no 1 tahun 2011, dengan visi untuk menciptakan hunian yang layak huni, cerminan pembinaan keluarga, harkat, martabat dan asset bagi pemiliknya, pemerintah juga telah membuat kebijakan terkait pengadaan Ruang Terpadu Ramah Anak (RPTRA) sebagai usaha untuk membangun interaksi sosial antar warga pada lingkungan berkepadatan tinggi. Tujuan dibangunnya RPTRA adalah sebagai fasilitas masyarakat yang dapat digunakan dan dimanfaatkan sebagai pusat interaksi publik sekaligus sebagai media pembelajaran dan pengembangan minat dan bakat yang aman serta baik untuk anak-anak. (Samsudin, \& Artiningrum, 2017). Namun, RPTRA ini belum secara optimal bersinergi langsung dengan pengadaan dan peremajaan rumah susun milik pemda.

\section{Ruang Publik Ramah Anak di Rusunawa}

Ruang publik merupakan ruang yang berfungsi sebagai ruang sosial, yaitu sebagai salah satu kebutuhan pokok pemukim untuk mengembangkan kehidupan bermasyarakat (Wellman \& Leighton, 1979). Persepsi lingkungan atau lanskap dapat mempengaruhi perilaku, motif, preferensi dan sikap pengguna, yang selanjutnya dapat menginformasikan perencanaan dan pengelolaan ruang hijau (Jim \& Shan, 2012). Pembentukan perilaku penghuni di Rusunawa Tambora baru juga tidak terlepas dari keaktifan fungsi ruang sosial seperti yang diungkapkan oleh teori Heimsath, bahwa perilaku penghuni merupakan proses interaksi yang melibatkan motivasi dan kebutuhan-kebutuhan individual maupun sosial (Indyastari, 2005). Penduduk mempengaruhi dan dipengaruhi oleh perilaku lingkungan mereka, dan kualitas sosial mereka berdampak pada isu sosial dan bentuk fisik ruang yang memperkaya aktivitas dan pengalaman hidup mereka (Lewis, 2005). Proses tumbuh kembang anak juga tidak terlepas dari pengalaman dalam mengeksplorasi dunia dewasa. Kalau anak-anak tidak bisa mengeksplorasi dunia dewasa di sekitar mereka, maka mereka tidak bisa menjadi dewasa dengan baik (Thomas, 1997). Anak juga mempunyai kebutuhan berinteraksi dengan anak lain. Kalau anak tidak cukup bermain dengan anak lain, di lima tahun pertama usianya, ada kemungkinan mereka akan menderita penyakit mental anak (Thomas, 1997).

Menurut Pedoman Teknis Pembangunan Rusunawa (UU No 20 Tahun 2011) yang dapat dikategorikan sebagai ruang publik di dalam lingkungan rusunawa adalah ruang bersama (koridor, lift, tangga, aula, dan ruang komunal di setiap lantai), fasilitas bersama (PAUD, perpustakaan dan sebagainya) dan bagian bersama (taman, halaman, tempat parkir, dan sebagainya). Mengacu pada peraturan tersebut, obyek utama dalam penelitian ini adalah ruang bersama dan fasilitas bersama dan taman bermain anak.

\section{Peremajaan Rusunawa Tambora}

Salah satu rusunawa yang dibangun di era tahun 1984 , seluas $21.734 \mathrm{~m}^{2}$ dan mengalami peremajaan adalah rusunawa Tambora (Ratnaningrum \& Suteja, 2012). Rusunawa ini berada di Jalan Angke Jaya, Kelurahan Angke, Tambora, Kota Administratif Jakarta Barat. Kondisi 
Rusunawa Tambora yang berkembang menjadi sangat kumuh setelah \pm 28 tahun ini telah mengalami peremajaan fisik secara total pada awal tahun 2015. Meskipun telah mengalami peremajaan bangunan meliputi bentuk bangunan; jumlah, tipe dan luasan unit hunian; tinggi lantai Rusunawa Tambora; karakter ruang bersama; dan fasilitas bersama, banyak penghuni yang setuju bahwa fasilitas interaksi sosial dan bermain anak masih dinilai kurang (Suteja, Ratnaningrum, \& Anggraini, 2016).

\section{Rumusan Masalah}

Persoalan yang diangkat dalam penelitian ini adalah untuk menindaklanjuti isu yang didapat dalam penelitian sebelumnya, yang menunjukkan bahwa banyak penghuni merasa fasilitas interaksi sosial dan bermain anak masih dinilai kurang (Suteja, Ratnaningrum, \& Anggraini 2016). Sehingga rumusan adalah:

- Apakah fasilitas/wadah interaksi sosial dan tempat bermain anak sudah memenuhi kebutuhan warga penghuni Rusunawa Tambora baru ditinjau dari aspek fungsional, teknis dan perilaku penggunanya?

- Bagaimana perencanaan suatu fasilitas/wadah interaksi sosial dan tempat bermain anak yang memenuhi syarat ditinjau dari aspek fungsional khususnya dalam hal tata ruang dan aspek teknis yang menyangkut keamanan, kenyamanan dan kekuatannya.

\section{Ruang Lingkup dan Tujuan Penelitian}

Penelitian ini akan difokuskan kepada evaluasi terhadap aspek fungsional dan teknis namun tetap mempertimbangkan persepsi dan pendapat serta perilaku penghuni dalam memanfaatkan ruangruang bersama, fasilitas bersama dan ruang bermain anak di Rusunawa Tambora baru. Tujuan penelitian ini adalah untuk memberikan masukan bagi perancangan dan penyediaan ruang publik sebagai ruang interaksi sosial yang ramah anak pada pembangunan atau peremajaan rusunawarusunawa berlantai tinggi di Jakarta. Penelitian ini juga diharapkan dapat memberikan rekomendasi bagi dinas terkait dalam penambahan atau perbaikan sarana dan prasarana untuk mencapai keberhasilan interaksi sosial warga dan ruang ramah anak yang lebih baik.

\section{METODE PENELITIAN}

Penelitian ini menggunakan metode kualitatif deskriptif dengan fokus dalam memperhatikan permasalahan yang terjadi di suatu lokasi/lingkungan yang bersifat spesifik dan memerlukan pendalaman terhadap persoalan yang dihadapi. Penelitian diarahkan untuk mengamati gejalagejala atau kejadian-kejadian secara sistematis dan akurat mengenai sifat-sifat populasi tertentu (Zuriah, 2007). Menurut metode kualitatif kebenaran adalah dinamis dan hanya dapat ditemukan melalui penelaahan terhadap orang-orang melalui interaksinya dengan situasi sosial mereka (Sudarwan, 2002), sehingga pendekatan ini menggunakan lingkungan alamiah sebagai sumber data. Peristiwa-peristiwa yang terjadi dalam suatu situasi sosial merupakan kajian utama penelitian ini. Data yang diperoleh seperti hasil pengamatan, hasil wawancara, hasil pemotretan, analisis dokumen, catatan lapangan disusun peneliti di lokasi penelitian. Sasaran khususnya pengguna ruang publik di Rusunawa Tambora baru baik anak-anak (prioritas), remaja, orang dewasa dan lansia yang sebelumnya merupakan penghuni Rusun Tambora lama.

\section{Metode Evaluasi Pasca Huni dan Pengumpulan Data}

Metode evaluasi pasca huni merupakan kegiatan peninjauan (pengkajian) kembali (evaluasi) terhadap bangunan-bangunan dan atau lingkungan binaan yang telah dihuni (Sudibyo, 1989 dalam elearning.gunadarma.ac.id). Metode ini merupakan bagian dari rentetan kegiatan di dalam proses pembangunan dimana kajian atas suatu bangunan yang telah dipergunakan (dihuni) dilakukan secara seksama dan sistematis untuk menilai apakah kinerja bangunan tersebut sejalan 
dengan kriteria perancangannya. Evaluasi pasca huni mencakup tiga aspek yaitu fungsional, teknis dan perilaku (Preiser, dkk, 1998). Aspek fungsional menyangkut aspek bangunan yang secara langsung mendukung kegiatan pemakai. Misalnya tata ruang dan sirkulasi. Aspek teknis meliputi keamanan, kenyamanan dan kekuatan/keawetan bangunan. Sedang aspek perilaku menghubungkan kegiatan pemakai dengan lingkungan fisiknya. Evaluasi perilaku mencakup bagaimana kesejahteraan sosial dan psikologis pemakai dipengaruhi oleh rancangan bangunan/lingkungan binaan. Beberapa permasalahan perilaku yang perlu diperhatikan antara lain proximity dan territoriality, privacy dan interaksi, persepsi, citra dan makna, kognisi dan orientasi (Sudibyo,1989).

Metode pengumpulan data meliputi:

1. survey pendahuluan dengan observasi secara menyeluruh terhadap beberapa fasilitas ruang publik ramah anak di Rusunawa Tambora dan wawancara yang bersifat free talk dengan bantuan informan kunci yang akan dilibatkan dalam kegiatan FGD (Focus Grup Discussion);

2. pengamatan partisipatif yang dilakukan secara pasif, peneliti membatasi diri untuk melakukan komunikasi dengan obyek yang diamati agar tidak terlalu banyak mengintervensi perilaku obyek (anak) dalam memanfaatkan ruang publik

3. FGD (Focus Grup Discussion), untuk menjaring pendapat dan harapan penghuni dan pengguna ruang publik khususnya yang melayani kegiatan anak. FGD dibagi dalam 2 kelompok pengguna secara terpisah, sesuai Guidelines for Conducting an FGD sekitar 10 orang per kelompok, yaitu kelompok anak-anak dan kelompok dewasa-lansia. Proses FGD dengan pertanyaan-pertanyaan utama/topik utama dan pertanyaan pengembangan dan diakhiri dengan pertanyaan penutup yang menghimpun hal-hal yang belum tersentuh dalam diskusi sebelumnya

4. Pengumpulan data penunjang. Dilakukan kepada 100 reponden penghuni Rusunawa Tambora Baru dan dipilih secara random sampling bersistimatis untuk mengetahui profil penghuni, pendapat mereka tentang ruang publik dan ruang bersama yang ada saat ini. Responden dipilih berdasarkan pertimbangan dapat merepresentasikan kondisi penghuni yang tinggal di unit-unit yang berada di blok A, B dan C, serta tinggal di lantai yang bervariasi.

Pengolahan data kemudian dilakukan dengan proses klasifikasi, deskripsi, interpretasi dan disajikan melalui penyajian data berupa gambar, foto, bagan, grafik, tabel maupun uraian pembahasan yang secara sistematis diarahkan untuk menjawab atau menjelaskan permasalahan penelitian.

\section{Metode Analisis}

Metode analisis dalam penelitian ini mengacu pada metode evaluasi pasca huni dengan meninjau kondisi fisik spasial ruang-ruang bersama, fasilitas bersama dan taman bermain anak di Rusunawa Tambora baru (sebagai variable bebas) dan pola pemanfaatan serta perilaku penggunanya (sebagai variable terikat). Dengan hipotesa kerja sebagai berikut:

- Kondisi suatu ruang bersama, fasilitas bersama dan taman bermain anak yang sesuai dengan prinsip perencanaan spasial-fungsional akan mendukung aktivitas penggunanya.

- Kondisi fisik suatu ruang bersama, fasilitas bersama dan taman bermain anak yang mengacu pada standar perencanaan yang tepat, akan membuat fasilitas tersebut dapat berfungsi sesuai kebutuhan pengguna secara aman dan nyaman digunakan

\section{HASIL DAN PEMBAHASAN}

Untuk menjawab apakah fasilitas/wadah interaksi sosial dan tempat bermain anak sudah memenuhi kebutuhan warga penghuni Rusunawa Tambora baru ditinjau dari aspek 
fungsional, teknis dan perilaku penggunanya, maka langkah-langkah pembahasannya adalah sebagai berikut:

\section{Tempat yang biasa digunakan untuk bermain sehari-hari:}

Sebagian besar informan anak mengatakan bahwa waktu bermain sangat jarang/sedikit pada hari Senin sampai Jumat dan banyak pada hari Sabtu dan Minggu. Sepulang sekolah dan setelah mereka beristirahat, umumnya anak-anak belajar mengaji hingga waktu Isya atau membantu ibunya menjaga warung/toko. Area yang paling sering menjadi tempat bermain mereka adalah di sepanjang koridor dan ruang komunal di lantai masing-masing. Anak-anak perempuan biasanya bermain bekel, congklak, bermain peran (pasar-pasaran, adik kakak dan sebagainya) atau sekedar mengobrol. Berikut ini adalah ruang-ruang komunal yang tersebar di tiap lantai yang dipergunakan oleh anak-anak dalam keseharian mereka.

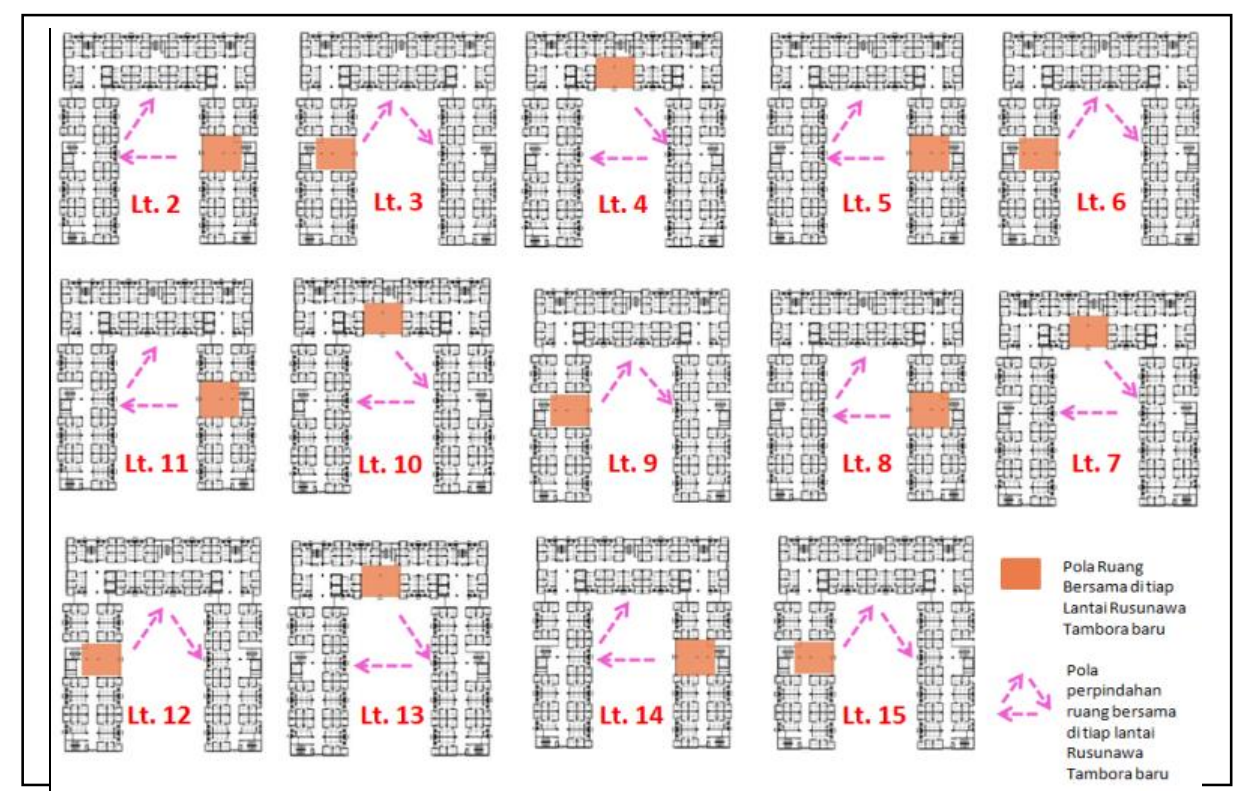

Gambar 1. Pola sebaran ruang bersama di tiap lantai unit hunian Sumber Gambar: Analisis Tim Peneliti, 2016

Sementara itu, walaupun aula di lantai dasar cukup luas dan tidak ada perabot, mereka tidak sering memanfaatkannya untuk bermain, karena lokasi yang jauh dari unit mereka di atas. Taman bermain di halaman Rusunawa lebih banyak dimanfaatkan pada hari libur. Hampir semua informan anak (usia SD maupun SMP) mengatakan mereka sering bermain di taman itu karena terdapat beberapa fasilitas bermain seperti ayunan, panjatan dan papan jungkit, yang sebetulnya adalah diprioritaskan untuk anak-anak PAUD. Remaja/SMP mengatakan bahwa mereka tidak mempunyai tempat yang nyaman untuk bersosialisasi, sehingga taman tersebut menjadi area yang cocok untuk bersosialisasi. Frekuensi seringnya penggunaan taman oleh anak dari luar Rusunawa Tambora, menyebabkan fasilitas yang ada menjadi sangat terbatas dan kurang bagi 
penghuni. Di sekitar taman terdapat fasilitas seperti PAUD, perpustakaan dan dua buah aula yang dari sisi perancangan sudah cukup baik dan diharapkan dapat saling bersinergi (gambar 2).

Posisi taman cukup terbuka dari jalan umum dan mudah diakses oleh siapa saja, termasuk anakanak yang tinggal di luar kompleks Rusunawa Tambora baru. Persoalan yang banyak dikeluhkan warga adalah cukup banyak anak-anak yang berasal dari luar Rusunawa Tambora baru yang bermain dan mengokupasi taman sehingga fasilitas yang ada menjadi sangat terbatas dan kurang bagi penghuni. Hal ini menunjukkan bahwa masuknya pihak luar telah menyebabkan teritorialitas dan proximity penghuni di ruang bersama mereka yang terbatas semakin terganggu.

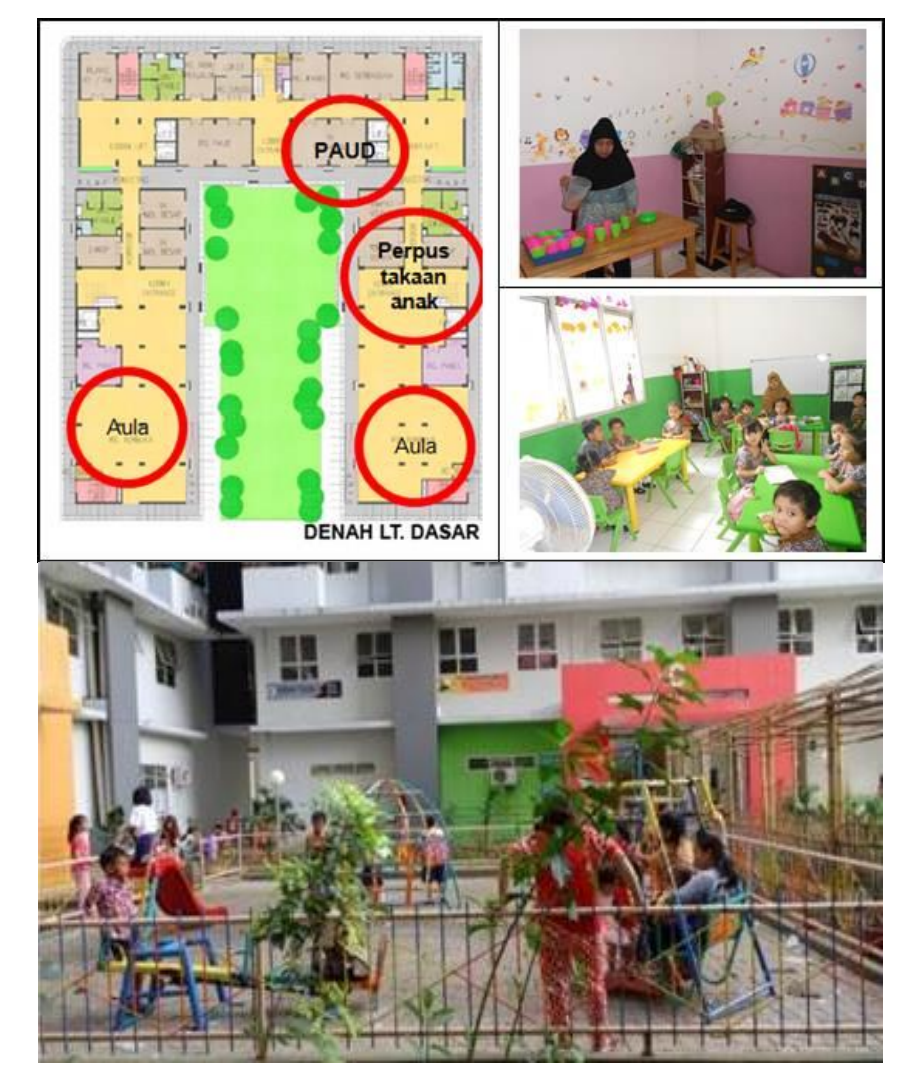

\section{Gambar 2. Fasilitas Taman, Aula, Paud, Perpus di lantai dasar} Sumber Gambar: Analisis Tim Peneliti, 2016

\section{Sosialisasi dan Interaksi Antar Warga Penghuni}

Meskipun dari sisi konektifitas antar blok di Rusunawa Tambora cukup baik, namun hasil FGD memperlihatkan bahwa diantara anak dalam satu blok Rusunawa Tambora tidak banyak yang saling kenal. Umumnya mereka baru kenal bila teman satu sekolah, teman satu lantai atau teman sesama penghuni Rusunawa Tambora lama. Begitu pula dengan informan orang tua yang mengatakan bahwa semenjak mereka tinggal di rusunawa Tambora baru, mereka juga belum mengenal seluruh penghuni di lantai yang sama. Hal ini berbeda dari kondisi di Rusunawa Tambora lama (yang telah mereka huni cukup lama). Menurut pendapat informan dewasa, sistem double loaded pada desain koridor rusun saat ini kurang membuat mereka dapat berinteraksi, sedang desain Rusunawa Tambora lama yang mempunyai void dengan konsep koridor single loaded, lebih memberikan view yang luas untuk bisa saling mengamati dan bertegur sapa di antara penghuni yang berseberangan. 


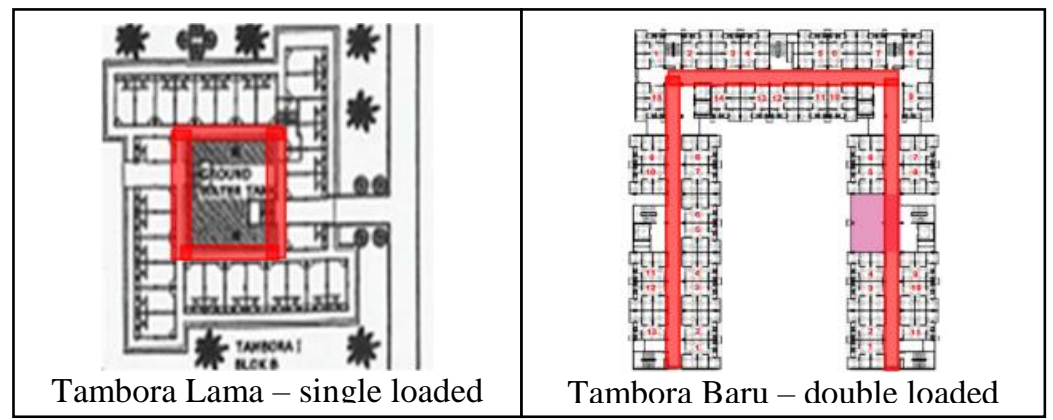

\section{Gambar 3. Perbedaan Ruang Interaksi Rusun Tambora Lama dan Baru}

Sumber Gambar: Analisis Tim Peneliti, 2016

\section{Ruang Publik Anak di Rusunawa Tambora Pasca Peremajaan}

\section{a. Analisis Ruang Publik Anak di Rusunawa Tambora}

Berdasarkan SNI 1733 - tahun 2004 tentang Tata Cara Perencanaan Lingkungan Perumahan di Perkotaan, sarana taman/tempat bermain ditetapkan $1 \mathrm{~m}^{2} /$ jiwa, untuk penduduk pendukung 250 orang (setara $1 \mathrm{RT}$ ). Untuk jumlah penduduk sebesar 2500 jiwa diperlukan lahan untuk Taman/tempat bermain seluas $1.250 \mathrm{~m} 2$ atau $0.5 \mathrm{~m} 2 /$ jiwa. Sementara itu kebutuhan akan Taman kanak-kanak/PAUD adalah $0.28 \mathrm{~m} 2 /$ jiwa atau seluas $216 \mathrm{~m}^{2}$ per 1.250 penduduk, dengan radius pencapaian maksimal $500 \mathrm{~m}$. Dalam ruang publik anak seharusnya tersedianya ruang untuk tempat berkumpul dan bersosialiasi dalam skala yang kecil dan besar (Senda dalam Chairunnisa, 2011). Lokasi, tata letak, peralatan bermain, konstruksi, serta material merupakan aspek penting yang harus diperhatikan dalam taman bermain anak (Baskara dalam Samsudin \& Artiningrum, 2017). Berikut adalah analisis ruang publik anak di rusunawa Tambora:

Tabel 1. Ruang Publik Anak di Rusunawa Tambora

\begin{tabular}{|c|c|c|c|c|c|}
\hline No & Rasio Pelayanan & Keterangan & TM & $\mathbf{M}$ & SM \\
\hline 1 & $\begin{array}{l}\text { Luas taman/taman } \\
\text { bermain diperlukan } \\
1.250 \mathrm{~m} 2\end{array}$ & $\begin{array}{l}\text { Tempat bermain anak yang dimaksud dengan luasan } 1066 \\
\mathrm{~m}^{2} \text {, berupa ruang terbuka saja, dengan fasilitas yang minim } \\
\text { dan ruang parkir. Taman kanak-kanak dirasa penghuni } \\
\text { kurang, minim kapasitas }\end{array}$ & V & & \\
\hline 2 & $\begin{array}{l}\text { Luas PAUD yang } \\
\text { dibutuhkan untuk } \\
2000 \text { warga adalah } \\
\text { sekitar } 400 \mathrm{~m} 2\end{array}$ & $\begin{array}{l}\text { Saat ini luas ruang kelas PAUD adalah } 40 \mathrm{~m} 2 \text {. Fasilitas } \\
\text { pendukung berupa taman bermain digunakan bersama } \\
\text { dengan anak-anak lalin non PAUD }\end{array}$ & V & & \\
\hline 3 & $\begin{array}{l}\text { Jarak pencapaian } \\
\text { maksimal } 500 \\
\text { meter }\end{array}$ & $\begin{array}{l}\text { Jarak cukup dekat kurang dari } 500 \text { meter dan dapat digapai } \\
\text { tidak hanya oleh Penghuni Rusunawa Tambora baru, tetapi } \\
\text { juga oleh sekitarnya }\end{array}$ & & & $\mathrm{V}$ \\
\hline
\end{tabular}

Sumber tabel: Analisis Tim Peneliti, 2016

\section{b. Analisis Kriteria lokasi}

Lokasi taman bermain berada di antara 3 tower dan tepat berada di area tengah halaman dalam dengan jarak dan akses yang mudah untuk dicapai oleh ketiga tower. Penempatan lokasi taman pada area yang seminimal mungkin anak - anak tidak mendapatkan gangguan/konflik saat perjalanan mencapai lokasi (Baskara dalam Samsudin \& Artiningrum, 2017). Lokasi taman bermain tidak ditempatkan pada area dengan tingkat gangguan kesehatan yang tinggi terutama polusi udara, air, bunyi, penciuman (bau) yang dapat mempengaruhi aktivitas bermain anak. (Baskara dalam Samsudin \& Artiningrum, 2017). Berikut adalah analisis yang ditemukan: 
Tabel 2. Analisis Persyaratan Lokasi di Rusunawa Tambora

\begin{tabular}{|c|c|c|c|c|c|}
\hline No & Persyaratan Lokasi & Keterangan & TM & $\mathbf{M}$ & SM \\
\hline 1 & Aksesibilitas & $\begin{array}{l}\text { Mudah dan terhubung dengan jalur jalan dari masing- } \\
\text { masing tower }\end{array}$ & & & $\mathrm{V}$ \\
\hline 2 & $\begin{array}{l}\text { Gangguan dari } \\
\text { lingkungan (kendaraan } \\
\text { bermotor) }\end{array}$ & Tidak ada & & & $\mathrm{V}$ \\
\hline 3 & $\begin{array}{l}\text { Gangguan terhadap } \\
\text { sekitar }\end{array}$ & Tidak ada & & & $\mathrm{V}$ \\
\hline 4 & Sehat dan bebas polusi & $\begin{array}{l}\text { Memenuhi, udara cukup segar berdekatan dengan taman } \\
\text { lingkungan }\end{array}$ & & & $\mathrm{V}$ \\
\hline 5 & Gangguan keamanan & $\begin{array}{l}\text { Masih ada intruder, anak-anak dari luar lingkungan yang } \\
\text { turut bermain, dan mengokupasi peralatan permainan. }\end{array}$ & $\mathrm{V}$ & & \\
\hline 6 & $\begin{array}{l}\text { Pembatasan akses ke } \\
\text { dalam taman }\end{array}$ & Berpagar tetapi tidak ada control & & $\mathrm{V}$ & \\
\hline 7 & Pagar & $\begin{array}{l}\text { Ada namun bersifat sementara, desain masih bisa } \\
\text { dipanjat. }\end{array}$ & & $\mathrm{V}$ & \\
\hline \multicolumn{6}{|c|}{ Keterangan: $\boldsymbol{T M}=$ Tidak Memenuhi, $\boldsymbol{M}=$ Memenuhi, $\mathbf{S M}=$ Sangat Memenuhi } \\
\hline
\end{tabular}

c. Analisis Pengelompokan Permainan Berdasar Usia

Taman bermain di rusunawa Tambora semula didesain untuk memfasilitasi anak-anak PAUD yang berada di lantai dasar tower $\mathrm{C}$, dengan jarak kurang dari $20 \mathrm{~m}$ dari taman tersebut. Sehingga jenis dan dimensi alat permainannya adalah untuk anak-anak usia 4-8 tahun. Seharusnya, terdapat ruang dengan media bermain anak yang dilengkapi dengan alat untuk bermain (Senda dalam Chairunnisa, 2011). Namun karena penghuni anak-anak tidak memiliki tempat bermain dan bersosialisasi, maka seringkali taman ini digunakan diluar kepentingan PAUD dan juga pendatang dari luar kompleks.

Tabel 3. Analisis Ruang Bermain Berdasarkan Pengelompokan Usia

\begin{tabular}{lllcc}
\hline No & Persyaratan Kelompok Usia & \multicolumn{1}{c}{ Keterangan } & TM & M SM \\
\hline 1 & Zona berdasar usia & $\begin{array}{l}\text { Desain untuk usia PAUD (3-5 tahun), tapi } \\
\text { dimanfaatkan juga oleh anak-anak yang lebih besar }\end{array}$ & V \\
\hline 2 & Pembatas antar kelompok usia & Masih tercampur & V & \\
\hline 3 & Pemisahan jenis permainan dan & Tidak ada & V \\
\hline
\end{tabular}




\begin{tabular}{llll}
\hline \multicolumn{3}{c}{$\begin{array}{l}\text { alat (misal luncuran), kolam } \\
\text { pasir dan area terbuka untuk } \\
\text { berlarian }\end{array}$} & \\
\hline 4 & $\begin{array}{l}\text { Pemisahan peralatan permainan } \\
\text { berdasar permainan favorit }\end{array}$ & $\begin{array}{l}\text { Letak peralatan permainan sudah tersebar dengan } \\
\text { jarak yang mencukupi dan semua jenis permainan } \\
\text { dimainkan secara merata. }\end{array}$ & $\mathrm{V}$ \\
\hline 5 & Kemudahan pengawasan & $\begin{array}{l}\text { Pagar transparan memudahkan orang tua/ pengasuh } \\
\text { melakukan pengawasan }\end{array}$ & $\mathrm{V}$ \\
\hline & Keterangan: $\boldsymbol{T M}=$ Tidak Memenuhi, $\boldsymbol{M}=$ Memenuhi, $\boldsymbol{S M}=$ Sangat Memenuhi
\end{tabular}

Sumber tabel: Analisis Tim Peneliti, 2016

d. Analisis perlengkapan dan material

Paving block berbahan dasar beton digunakan sebagai lantai penutup taman bermain rusunawa Tambora. Peralatan permainan umumnya terbuat dari metal dicat warna-warna menarik, kecuali fiber cetak yang digunakan pada permainan luncuran.

\section{Tabel 4. Analisis Ruang Bermain Berdasarkan Persyaratan Perlengkapan dan Material}

\begin{tabular}{|c|c|c|c|c|}
\hline No & $\begin{array}{c}\text { Persyaratan perlengkapan dan } \\
\text { material }\end{array}$ & Keterangan & $\mathbf{T M}$ & SM \\
\hline 1 & $\begin{array}{ll}\text { Bahan lantai } & \text { harus dapat } \\
\text { mengabsorbsi } & \text { tekanan/benda } \\
\text { jatuh } & \\
\end{array}$ & $\begin{array}{l}\text { Penggunaan paving block berbahan beton sangat } \\
\text { keras dan berbahaya saat anak-anak terjatuh } \\
\text { khususnya di bagian kepala. }\end{array}$ & $\mathrm{V}$ & \\
\hline 2 & $\begin{array}{l}\text { Pemilihan bahan harus bebas } \\
\text { racun dan karat }\end{array}$ & $\begin{array}{l}\text { Semua material besi dilapis dengan cat/pelapis, tapi } \\
\text { perlu dicek jenis cat yang digunakan. Sebagian } \\
\text { permainan sudah mulai terkelupas catnya }\end{array}$ & $\begin{array}{l}\text { cukup } \\
\text { memenuhi }\end{array}$ & \\
\hline 3 & $\begin{array}{l}\text { Sambungan dan baut harus kuat, } \\
\text { aman, terutama pada peralatan } \\
\text { yang bergerak. }\end{array}$ & $\begin{array}{l}\text { Kualitas sambungan masih cukup kuat, tetapi } \\
\text { diperlukan pengecekan berkala karena jenis bahan } \\
\text { besi kurang tahan cuaca. }\end{array}$ & $\mathrm{V}$ & \\
\hline 4 & $\begin{array}{l}\text { Desain mainan harus mudah } \\
\text { dibersihkan, } \\
\text { sambungannya dan diberi oli. }\end{array}$ & Cukup memenuhi pada alat permainan baru & $\mathrm{V}$ & \\
\hline 5 & $\begin{array}{l}\text { Material untuk luncuran, } \\
\text { dudukan dan pijakan kaki }\end{array}$ & $\begin{array}{l}\text { Sebagian besar masih menggunakan metal yang } \\
\text { berlapis cat. Pada siang hari alat ini terlindung } \\
\text { bayangan tower sehingga material metal tidak } \\
\text { menjadi panas. }\end{array}$ & V & \\
\hline & $T M$ & lak Memenuhi, $\boldsymbol{M}=$ Memenuhi, $\boldsymbol{S M}=$ Sangat Memenuh & & \\
\hline
\end{tabular}

Sumber tabel: Analisis Tim Peneliti, 2016

\section{e. Analisis Tempat Bermain di Dalam Ruangan}

Pada rusunawa ini tidak tersedia secara khusus tempat bermain indoor, tetapi beberapa ruangan seperti aula di lantai dasar dan ruang bersama yang tersebar di setiap lantai seringkali digunakan untuk bermain anak-anak. Jenis permainan di ruang aula lantai dasar umumnya anak-anak berkejar-kejaran, petak umpet, bersepeda, sepatu roda dan sebagainya. Sementara di ruang bersama di setiap lantai yang meluas penggunaannya sampai ke koridor yang saling terhubung antar 3 tower, anak lelaki seringkali bermain sepatu roda, dan sepeda selain bermain bola dan berlari-larian secara cepat.

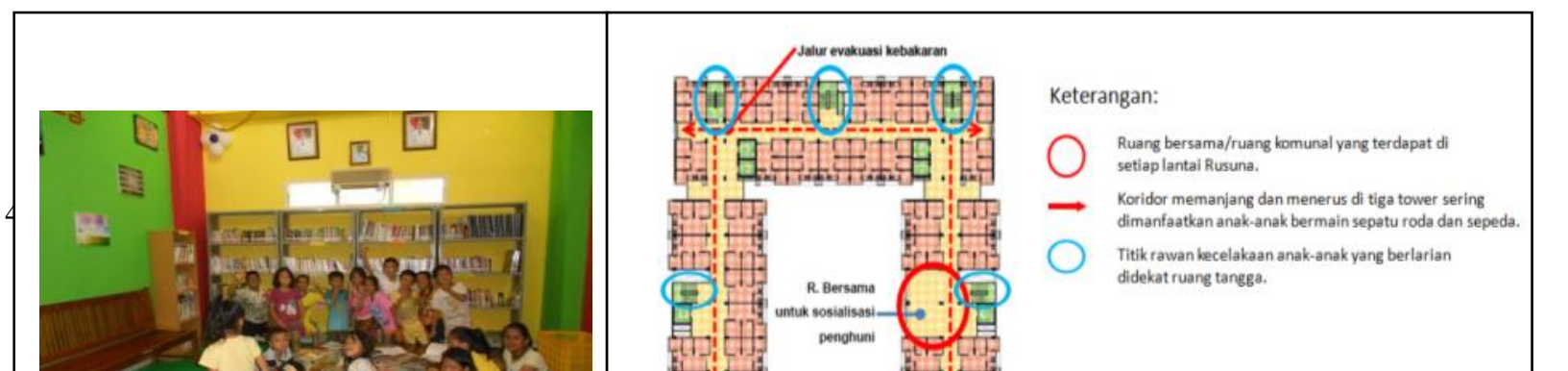




\section{Gambar 4. Perpustakaan dan letak ruang bersama di antara paud-ruang aula di lantai dasar}

Sumber Gambar: Hasil Survey dan Analisis Penulis, 2016

Sementara itu, anak-anak perempuan lebih sering bermain boneka, congklak, bekel atau hanya sekedar bercerita dan bermain peran. Titik rawan terutama pada ruang tangga yang terbuka tanpa pengaman, yang dikhawatirkan ada anak yang terjatuh saat bermain. Kegiatan bermain ini semakin intens pada saat libur sekolah dan seringkali hingga larut malam.

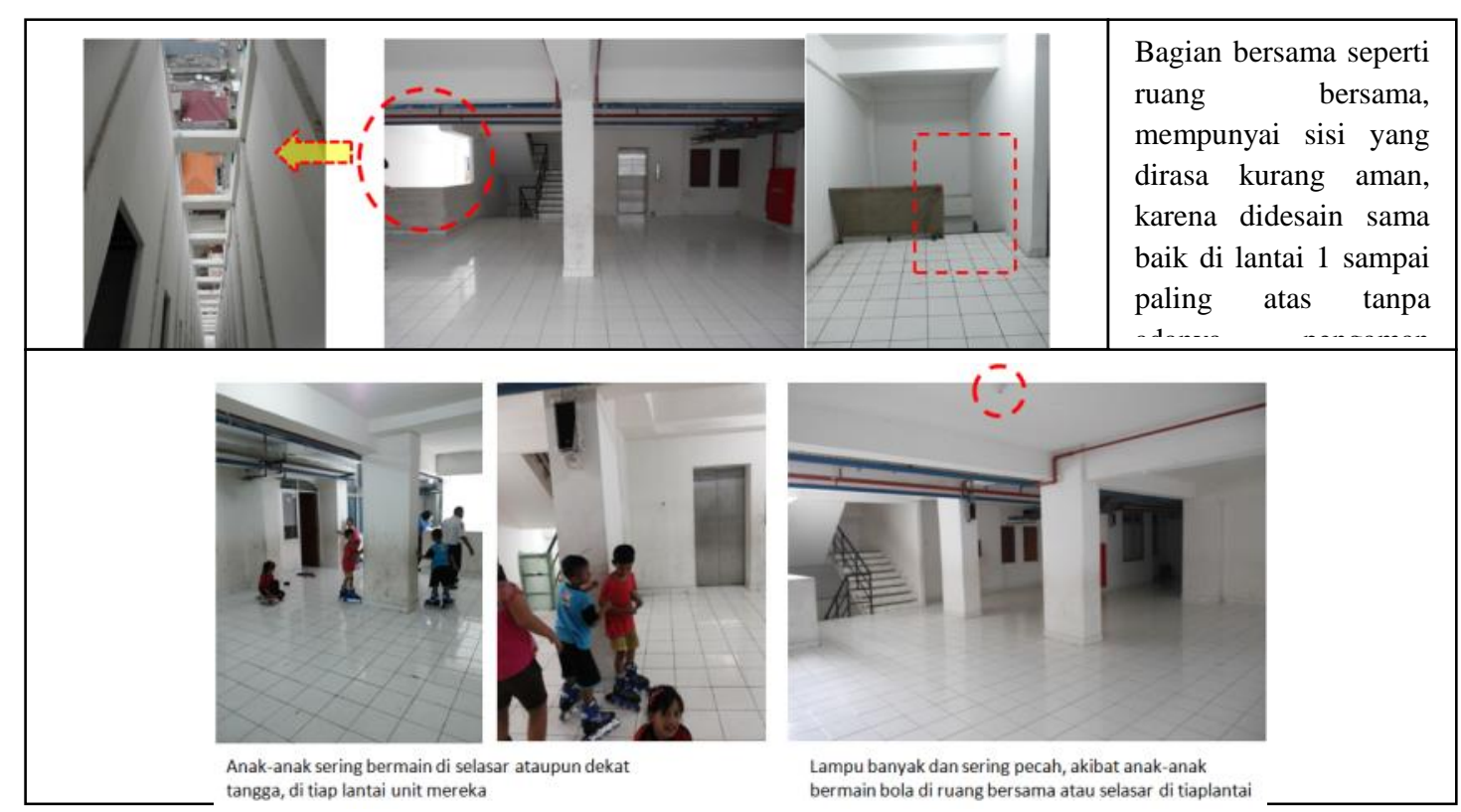

Gambar 5. Situasi ruang bersama di tiap lantai yang dirasa tidak aman Sumber Gambar: Hasil Survey dan Analisis Penulis, 2016

\section{KESIMPULAN DAN SARAN}

Dibandingkan dengan rusunawa Tambora lama, peremajaan rusunawa ini telah banyak menempatkan tambahan sarana dan prasarana yang mendukung kegiatan aktivitas belajar, bersosialisasi dan bermain bagi anak-anak. Jarak pencapaian sarana bermain anak sudah sesuai dengan standart yang dapat ditempuh dalam jarak kurang dari $500 \mathrm{~m}$, dan aksesibilitas mudah dan merata bagi semua tower menuju ke area bermain. Tidak ada gangguan terhadap kendaraan bermotor dan udara cukup segar dengan taman lingkungan yang baik. Alat dengan material metal memungkinkan mendapat shadow dari bangunan dan tidak cenderung panas pada saat dimainkan. Tetapi ada beberapa hal yang seharusnya dibenahi untuk lebih memenuhi kebutuhan kembang anak: 
1. Luas taman bermain tidak memenuhi standart kebutuhan ruang yang diperlukan, yaitu dibutuhkan setidaknya $1.250 \mathrm{~m} 2$ untuk penduduk sekitar 2000 orang

2. Luas PAUD tidak memenuhi standart kebutuhan ruang yang diperlukan, yaitu dibutuhkan luasan setidaknya $400 \mathrm{~m} 2$ untuk penduduk sekitar 2000 orang

3. Masih ada intruder, anak-anak dari luar lingkungan yang masuk dalam kompleks Rusunawa Tambora Baru

4. Walaupun sudah ada sistem keamanan, tetapi masih memungkinkan adanya gangguan

5. Walaupun sudah ada pagar, tetapi masih bisa untuk dipanjat

6. Belum adanya pemisahan area bermain berdasarkan usia

7. Belum adanya pemisahan area bermain berdasarkan jenis permainan basah dan kering

8. Walaupun pada lantai dasar pengawasan di area bermain dirasa mudah, bagian bersama di tiap lantai bangunan dirasa kurang aman sebagai area bermain, dikarenakan belum adanya railing atau pembatas yang tinggi.

9. Belum adanya bahan lantai yang terabsorsi dengan bantalan/ karet

10. Kualitas alat bermain cenderung mudah mengalami kerusakan

Pengadaan, perluasan atau pengolahan variasi ruang diperlukan pada tiap lantai, sehingga dapat memberikan lebih banyak alternatif ruang interaksi sosial penghuni yang tidak hanya dilantai dasar tetapi terpadu di setiap lantai. Perencanaan yang lebih matang, terkait jumlah permainan, aspek keamanan dan perawatan alat permainan khususnya bagi anak-anak, supaya tetap terjaga dan dapat dinikmati oleh anak-anak dan pernghuni pasca peremajaan rusunawa Tambora.

\section{Ucapan Terima Kasih (Acknowledgement)}

Penulisan ini merupakan bentuk pemikiran dan analisis dari penelitian tentang Rusuna Tambora, Jakarta, yang sudah dilakukan sejak bulan Juni tahun 2012 dengan bantuan hibah penelitian dari DPPM UNTAR. Foto Penjelas diambil dari hasil survey bersama tim survey lapangan antara dosen dan mahasiswa dengan bantuan dari Dinas Perumahan dan Gedung Pemda DKI Jakarta. Penulisan ini merupakan pemikiran bersama yang ditulis langsung oleh para penulis pada tahun 2016 dan merupakan detail serta pengembangan dari materi poster yang sudah pernah dipublikasikan di acara Research Week 2016, dengan judul "Evaluasi Pemanfaatan Ruang Publik Terpadu Ramah Anak Di Rusunawa Tambora Baru Jakarta"

\section{REFERENSI}

Anggraini, D. (1994). Permukiman Orang Betawi Suatau adaptasi terhadap Pemekaran Kota. Jakarta. Tesis Magister Antropologi, Program Pascasarjana, Program Studi Antropologi, Universitas Indonesia.

Boumeester, Harry J.F.M. (2011). Traditional Housing Demand Research. New York : Springer Dordrecht Heidelberg

Chairunnisa. (2011). Taman sebagai Pendukung Aktivitas Bermain Anak dan Berolahraga di Pemukiman (Studi Kasus Taman Amir Hamzah). Departemen Arsitektur Universitas Indonesia.

Indyastari, W. (2005). Efektifitas Ruang Publik di Rumah Susun, Teori Perilaku dan Lingkungan. ITB.

Irfiyanti, Z. \& Widjonarko. (2014). Penyediaan Rumah Susun Sederhana Sewa Ditinjau Dari Preferensi Masyarakat Berpenghasilan Rendah Di Kabupaten Kudus. Jurnal Teknik PWK, Vol. 3, No. 4.

Jim CY, Shan X. (2013). Socio economic effect on perception of urban green spaces in Guangzhou, China. Cities (31): 123-131.http://dx.doi.org/10.1016/j.cities.2012.06. 017 
Lewis, S. (2005). Front to Back: a design agenda for urban housing. Architectural Press, an imprint of Elsevier. Oxford. pp: xvi.

Preiser, W.F.E, Robinowitz, H.Z, and White, E.T.(1998). Post Occupancy Evaluation. New York: Von Nortsland Reinhold Company.

Purwaningsih, E., Tukiran, \& Giyarsih. (2011). Penyesuaian Diri Penghuni Rumah Susun Terhadap Lingkungan Tempat Tinggal. Majalah Geografi Indonesia, Vol. 25, No.2, 150161.

Ratnaningrum, D., Suteja, M.S. \& Anggraini, D. (2012). Pola Pemanfaatan Ruang Unit Hunian dan Selasar pada Rusunawa Tambora I dan II. Lembaga Penelitian dan Publikasi Ilmiah, Universitas Tarumanagara, Jakarta.

Samsudin \& Artiningrum, P. (2017). Evaluasi Kualitas Fisik dan Nonfisik pada Ruang Publik Terpadu Ramah Anak (RPTRA) Studi Kasus RPTRA Griya Tipar Cakung Jakarta Timur. Vitruvian Jurnal Arsitektur, Bangunan, \& Lingkungan, Vol.7, no.1, 31-40.

Sudarwan, D. (2002). Menjadi Peneliti Kualitatif. Cet. Ke1, h. 64. CV. Pustaka Setia, Bengkulu.

Suminah, N., Sulistyantara, B., \& Budiarti, T. (2017). Studi Persepsi dan Preferensi Penghuni Terhadap Ruang Hijau Di Rumah Susun Sederhana Sewa Provinsi Dki Jakarta Serta Strategi Perbaikannya. Jurnal Lanskap Indonesia, Vol. 9, No. 1, 36-51.

Suteja, M.S., Ratnaningrum, R., \& Anggraini, D. (2015). Pola Pemanfaatan Ruang Unit Hunian pada Rusunawa Tambora Baru, Jakarta. Lembaga Penelitian dan Publikasi Ilmiah, Universitas Tarumanagara, Jakarta.

Suteja, M.S., Ratnaningrum, R. (2016). Evaluasi Pemanfaatan Ruang Publik Terpadu Ramah Anak di Rusunawa Tambora Baru Jakarta. Lembaga Penelitian dan Publikasi Ilmiah, Universitas Tarumanagara, Jakarta.

Thomas, A. \& Chess, S. (1977). Temperament and Development. New York: Brunner/ Mazel.

Undang-Undang Republik Indonesia Nomor 26 tahun 2007. (2007). Tentang Penataan Ruang. Jakarta.

Wellman \& Leighton. (1979). Network, Neighborhoods and Communities: Approaches to the Study of The Community Question. Urban Affairs Quarterly, vol 14 No 3, 363-390.

Zuriah, N. (2007). Metodologi Penelitian Sosial dan Pendidikan. Cet. Ke-2, h. 47. Bumi Aksara, Jakarta. 